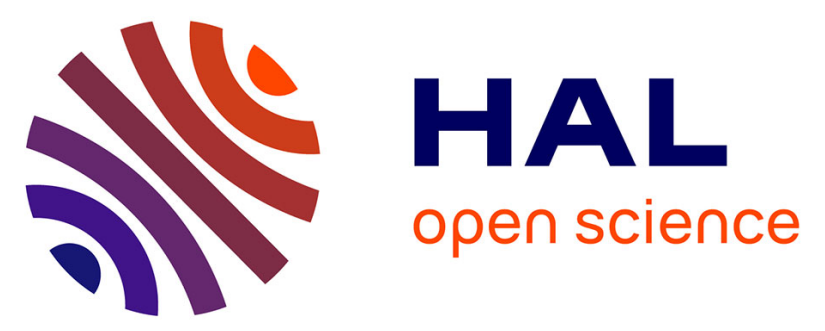

\title{
Coral- and oyster-microbialite patch reefs in the aftermath of the Triassic--Jurassic biotic crisis (Sinemurian, Southeast France)
}

Simon Boivin, Melanie Gretz, Bernard Lathuilière, Nicolas Olivier, Annachiara Bartolini, Rossana Martini

\section{- To cite this version:}

Simon Boivin, Melanie Gretz, Bernard Lathuilière, Nicolas Olivier, Annachiara Bartolini, et al.. Coraland oyster-microbialite patch reefs in the aftermath of the Triassic-Jurassic biotic crisis (Sinemurian, Southeast France). Swiss Journal of Geosciences, 2018, 10.1007/s00015-018-0310-y . hal-01785715

\author{
HAL Id: hal-01785715 \\ https://hal.uca.fr/hal-01785715
}

Submitted on 27 Nov 2021

HAL is a multi-disciplinary open access archive for the deposit and dissemination of scientific research documents, whether they are published or not. The documents may come from teaching and research institutions in France or abroad, or from public or private research centers.
L'archive ouverte pluridisciplinaire HAL, est destinée au dépôt et à la diffusion de documents scientifiques de niveau recherche, publiés ou non, émanant des établissements d'enseignement et de recherche français ou étrangers, des laboratoires publics ou privés. 


\title{
Coral- and oyster-microbialite patch reefs in the aftermath of the Triassic-Jurassic biotic crisis (Sinemurian, Southeast France)
}

\author{
Simon Boivin ${ }^{1}\left(\mathbb{D} \cdot\right.$ Mélanie Gretz $^{1} \cdot$ Bernard Lathuilière $^{2} \cdot$ Nicolas Olivier $^{3} \cdot$ Annachiara Bartolini $^{4} \cdot$ Rossana $^{-}$ \\ Martini $^{1}$
}

Received: 8 December 2017 / Accepted: 4 April 2018/Published online: 2 May 2018

(C) Swiss Geological Society 2018

\begin{abstract}
The end of the Triassic and the Early Jurassic are intervals characterised by profound biotic and environmental changes, accompanied by dramatic decreases in marine fauna diversity. Corals were strongly affected and assemblages underwent a severe reduction; compared with those of the Upper Triassic, the Early Jurassic is traditionally defined as holding a "reef gap". A Sinemurian coral-microbialites patch reef, located in southern France in the Hérault department (Le Perthus locality), is here described. This bioconstruction developed in a shallow mixed siliciclastic-carbonate inner ramp setting. The reef volume is composed of up to $70 \%$ of an intercoral facies mostly microbialites, with subordinated sediments (approximately 20-30\% of the intercoral facies). Therefore, the patch reef can be defined as a coral-microbialite bioconstruction, in which microbialites were the main framebuilders. The coral assemblage has low diversity and is dominated by massive to branching colonies of Chondrocoenia clavellata. This highlights the reef diversity after the T/J boundary crisis. The Le Perthus patch reef could have acted as an edge for the dominant currents and probably induced reductions in hydrodynamic energy and sedimentation on one of its sides. Consequently, it could have triggered the growth of small lateral bioconstructions, composed of oysters and microbialites, uniquely on one of its sides. The evolution of the facies shows that the Le Perthus patch reef grew in a shallowing-upward setting accompanied by an increase in siliciclastic inputs. The rate of bioerosion and the faunal assemblage suggest that the bioconstructions could have been developed in a mesotrophic environment.
\end{abstract}

Keywords Sinemurian · Early Jurassic · Corals · Microbialites · Patch reef · Depositional environment · Southern France

\section{Introduction}

Editorial handling: Silvia Spezzaferri.

Electronic supplementary material The online version of this article (https://doi.org/10.1007/s00015-018-0310-y) contains supplementary material, which is available to authorized users.

Simon Boivin

simon.boivin@unige.ch

1 Department of Earth Sciences, University of Geneva, 13 Rue des Maraîchers, 1205 Geneva, Switzerland

2 Université de Lorraine, CNRS, Laboratorie GeoRessources, UMR 7359, BP 70239, 54506 Vandoeuvre-lès-Nancy Cedex, France

3 Université Clermont Auvergne, CNRS, Laboratoire Magmas et Volcans, 63000 Clermont-Ferrand, France
The Triassic-Jurassic (T-J) boundary, which is estimated ca. 201 million years ago (Schaltegger et al. 2008; Schoene et al. 2010), is considered to mark one of the five largest mass extinctions of the Phanerozoic (e.g., Newell 1963; Raup and

4 Muséum National d'Histoire Naturelle, Département Histoire de la Terre, USM 203 CNRS UMR 5143 Paléobiodiversité et Paléoenvironnements, 8 Rue Buffon CP38,

75231 Paris Cedex 05, France 
Sepkoski 1982; Benton 1995; Tanner et al. 2004). This interval is accompanied by profound biotic and environmental changes (Tanner et al. 2004; Van de Schootbrugge et al. 2007; Clémence et al. 2010a, b; Guex et al. 2012; Richoz et al. 2012). The causes of the T-J boundary biotic crisis remain controversial, and several scenarios have been proposed in the literature (e.g., sea level change, ocean anoxia, bolid impact, aridification of Pangaea, and release of sea-floor methane hydrates, $\mathrm{SO}_{2}$ and/or $\mathrm{CO}_{2}$ CAMP volcanism) (Newell 1963; Marzoli et al. 1999; McElwain et al. 1999, 2009; Ward et al. 2001; Pálfy et al. 2001; Tanner et al. 2001; Hesselbo et al. 2002; Olsen et al. 2002; Guex et al. 2004; Van de Schootbrugge et al. 2009; Schmieder et al. 2010; Ruhl et al. 2011; Schoene et al. 2010; Kasprak et al. 2015; Van de Schootbrugge and Wignall 2015; Guex et al. 2016). This crisis is mainly associated with a number of dramatic changes in the global carbon cycle (McElwain et al. 1999, 2009; Ward et al. 2001; Pálfy et al. 2001; Hesselbo et al.2002; Berner and Beerling 2007; Van de Schootbrugge et al. 2008; Ruhl et al. 2011; Bartolini et al. 2012), implying considerable increases in atmospheric $\mathrm{CO}_{2}$ that induced global warming. The principal, but most likely non-unique source of these $\mathrm{CO}_{2}$ emissions, was the Central Atlantic Magmatic Province (CAMP), which is one of the largest igneous provinces in the world, related to the break-up of Pangaea (Marzoli et al. 1999). A considerable increase in atmospheric $\mathrm{CO}_{2}$, and/or alternatively in volcanic sulphuric emissions at the end of the Triassic, caused $\mathrm{CaCO}_{3}$ undersaturation in the oceans, which consequently induced a biocalcification crisis characterised by high extinction rates of reef communities (Hautmann 2004, Hautmann 2006; Clémence et al. 2010a, b; McRoberts et al. 2012; Martindale et al. 2012; Hönish et al. 2012).

The Early Jurassic is traditionally considered as a "reef gap" (Flügel and Kiessling 2002; Stanley 2001). However, at several sites of Early Jurassic coral occurrences have been reported (e.g., Lathuilière and Marchal 2009; Melnikova and Roniewicz 2012; Gretz et al. 2013). Nevertheless, the global insight is that Hettangian and Sinemurian reefs were small and scarce on the Earth. Exceptions are the large Elmi's reef, redescribed by Kiessling et al. (2009), and the British Columbian reef described by Stanley and McRoberts (1993). During the Pliensbachian, reefs were abundant mainly in the western Tethys, but corals were rarer than lithiotid bivalves (Kiessling et al. 1999). The Pliensbachian ended with an extinction of coral taxa (Lathuilière and Marchal 2009) and a severe decrease in reef growth (Kiessling 2011). The Early Liassic witnessed a profound modifications in coral reefs composition, biodiversity, architecture, skeletal density, and ecological parameters (Kiessling et al. 2007). Their ecology, taxonomy, and paleobiogeography are still poorly investigated (Stanley and McRoberts 1993; Kiessling et al. 2009; Gretz et al. 2013, 2015). The Lower Liassic reef crisis marked (i) a break between different types of reefs, (ii) a disruption between the declining Triassic and the emergence of new Jurassic coral families, and (iii) a break between two periods of widespread reef building in the Upper Triassic and Middle Jurassic. Therefore, each new case study improves our knowledge of the process of post-extinction recovery.

Melas (1982) and Hamon (2004) briefly mentioned a poorly known Upper-Sinemurian patch reef in southern France in the Hérault department (Le Perthus locality). The aim of this study is a detailed analysis of the palaeoecological and palaeoenvironmental conditions in which this Sinemurian coral-microbialite patch reef developed.

\section{Geographical, geological and sedimentological setting}

The studied patch reef is located in the Lodève region, Hérault department (Languedoc-Roussillon region, southern France) (Fig. 1). It outcrops in the tiny hamlet of Le Perthus, where a continuous and accessible Permian to Dogger succession is exposed (e.g., Melas 1982; Arrondeau 1982; Hamon 2004; Hamon and Merzeraud 2007). The coral-microbialite patch reef is well visible on one side of main road D902 (GPS coordinates $43^{\circ} 46^{\prime} 650^{\prime \prime} \mathrm{N} / 3^{\circ} 15^{\prime} 302^{\prime \prime} \mathrm{E}$ ).

The Lodève region is set on the Caussenard High horst, and forms the boundary between the Causses Basin and the Southeast Basin (Hamon et al. 2005) (Fig. 1), which, during the Liassic, were connected (Michard et al. 1979; Alabouvette et al. 1988). The Southeast Basin has been documented as the westernmost part of the Tethyan Ocean (Baudrimont and Dubois 1977; Debrand-Passard et al. 1984; Hamon and Merzeraud 2007). From the Hettangian until the Toarcian, this zone was affected by an extensional phase characterised by the development of synsedimentary normal faults with SW-NE trends and by the rotation of fault blocks within the Liassic sediments (Baudrimont and Dubois 1977; Arrondeau 1982; Merzeraud and Colombié 1999; Hamon and Merzeraud 2007). These tectonic movements were related to the first opening episode of the Tethyan Ligurian Ocean (Hamon and Merzeraud 2007).

At Le Perthus, Sinemurian sediments are approximately $36 \mathrm{~m}$ thick and consist of shallow platform deposits (Online Resource 2). Following a relative sea-level rise, the depositional environment evolved from peritidal (mainly dolomitic rocks) to lagoonal facies (oncoid wackestones and bioturbated, argillaceous mudstone); then to oolitic sand shoal facies (fine to coarse-grained oolitic grainstones to packstones, with subordinate shales and wackestones with ostracods, pelecypods and dasycladacean algae), and finally to outer-shelf facies (shales, crinoid and annelid wackestones, and sponge spicule wackestones) (e.g., Hamon 2004; Hamon and Merzeraud 2007). 
Fig. 1 Location map of Le Perthus (Languedoc-Roussillon region, southern France) and sedimentary environments of the calcareous Liassic (Map modified from Baudrimont and Dubois 1977)

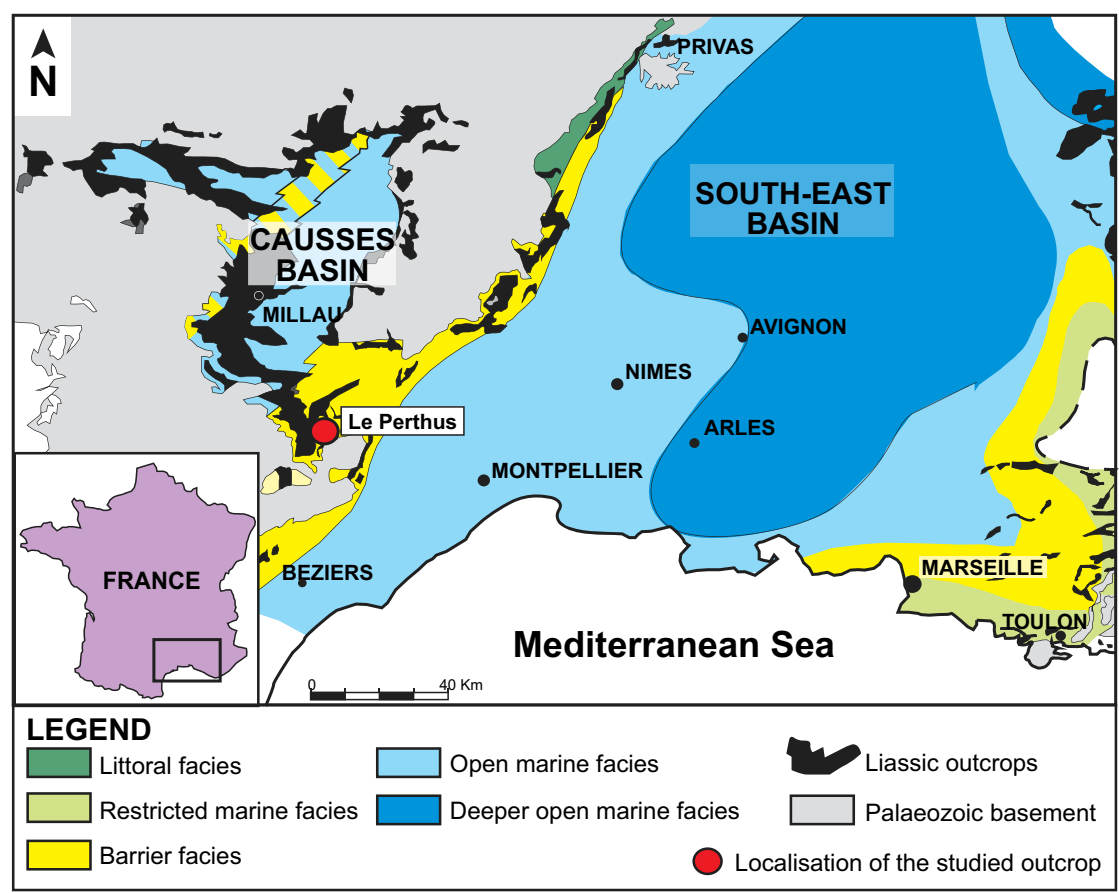

Based on facies and discontinuity surfaces, high-frequency metre-scale cycles (averaging 2-3 m) can be identified (Hamon 2004; Hamon et al. 2005; Hamon and Merzeraud 2007). They mostly consist of shallowing-upward cycles forming peritidal or subtidal cycles (Online Resource 2; Hamon 2004; Hamon and Merzeraud 2007). Peritidal cycles are represented by peritidal and/or lagoonal facies, whereas subtidal cycles are composed of oolitic sand shoal and/or outer-shelf facies. Based on a facies analysis and isotopic signals of $\delta^{13} \mathrm{C}$ and $\delta^{18} \mathrm{O}$, largescale cycles ( $3^{\text {rd }}$ order, thicknesses from 5 to $20 \mathrm{~m}$ ) were also recognised by Hamon and Merzeraud (2007).

Ammonites biostratigraphy has also been documented by Hamon and Merzeraud (2007), who recognized the interval spanning the Arietites bucklandi to the Asterooceras obtusum zones (Online Resource 2). Intercalated to pelagic deposits, bioconstructions can also be observed along the section. The largest bioconstruction is the studied coral-microbialite patch reef, hereafter named the Le Perthus patch reef (Fig. 2). This bioconstruction spans the upper part of the Sinemurian Asteroceras obstusum Ammonite Zone (Melas 1982; Hamon 2004) (Online Resource 2). However, it has never been studied in detail nor placed within its palaeoecological and palaeoenvironmental depositional contexts.

\section{Le Perthus patch reef and surrounding beds}

The Le Perthus coral-microbialite patch reef is approximately $1.9 \mathrm{~m}$ high and $2.1 \mathrm{~m}$ width, and its base is not visible (Fig. 2). The pattern of the observed surface shows an asymmetric lateral growth of the coral-microbialite patch reef, displaying roughly polished surface with a great number of silicified corals and bivalves with dark colour (Online Resource 3). Nevertheless, the finer structures of the corals are often obliterated by intense alteration. The macroscopic and microscopic observations reveal that the reef is composed of different types of organisms (Online Resources 4 and 5). Among them, corals are the main framebuilders and are represented by at least three genera. Their poor preservations make determinations at specific level difficult. However, based on morphological analogies with the Sinemurian corals of the nearby Lodève area (stored in the collections of the Museum-Aquarium of Nancy) the following species have been recognised: Lepidophyllia (Heterastraea) morencyana (Terquem and Piette 1865), Chondrocoenia clavellata (Terquem and Piette 1865) and Phacelostylophyllum?suttonensis (Duncan 1867). The L. (H.) morencyana includes massive colonies that are $6-11 \mathrm{~cm}$ in diameter (Fig. 3a, b). They are identified based on the cerioid arrangement and polygonal shape of the corallites. The colonies of $C$. clavellata generally display lamellar to ramose morphologies, with intermediate forms in between. Coral colonies are irregular, resulting in massive to pseudoramose morphologies (Fig. 3c, d). Their sizes are highly variable; the largest has a width of $24 \mathrm{~cm}$ width and height of $78 \mathrm{~cm}$. These corals have a cerioid to slightly plocoid arrangement and exhibit very small polygonal to rounded corallites, with a prominent columella (Fig. 3d). Finally, Phacelostylophyllum colonies are recognised by their phaceloid morphology. The branches are generally thin, with diameters of approximately $1 \mathrm{~cm}$ (Fig. 3e, f, g). 

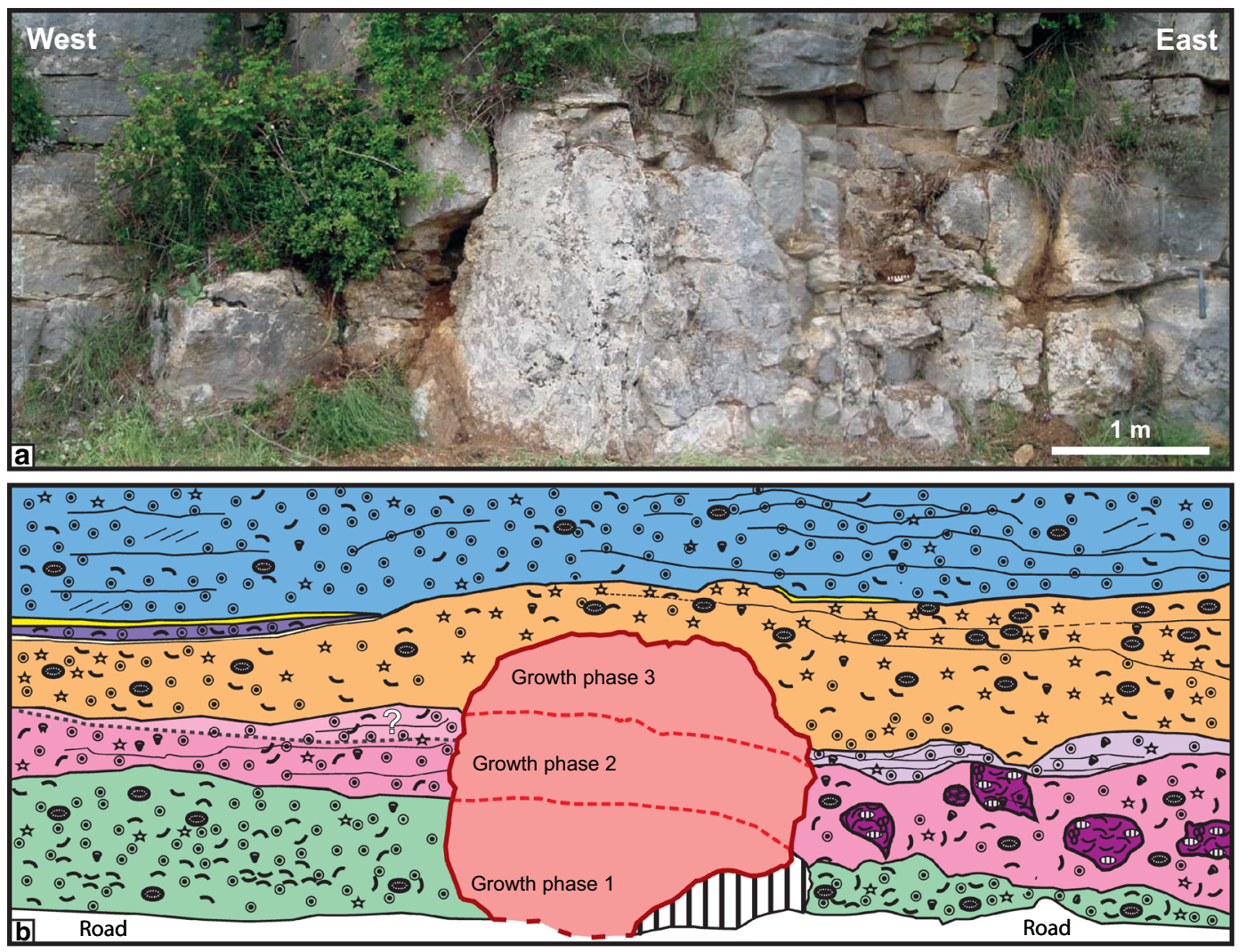

\begin{tabular}{|c|c|c|c|c|c|}
\hline \multicolumn{6}{|l|}{ Legend } \\
\hline 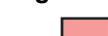 & Coral mi & obialite patch reef & & ○ Ooids & $\star$ Echinoderm fragments \\
\hline ए & Bed 1 & $\square$ Bed 3 & Bed 6 & Q Gastropods (often fragments) & 8 Colonial serpulids \\
\hline 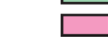 & Bed 2B & $\square$ Bed 4 & Bed 7 & Dacycladacean fragments & (IIID Microbialites \\
\hline & Bed 2C & $\square$ Bed 5 & Bed 8 & $\smile$ Bivalve shells (often fragments) & Demosponge spicules \\
\hline
\end{tabular}

Fig. 2 The Le Perthus patch reef and its surrounding beds. a Picture of the outcrop. b Sedimentological interpretation and geometrical relationship between the coral-microbialite patch reef and the lateral beds 1-8. Eight distinct beds can be identified (Online Resource 2).

Surrounding and overlapping the Le Perthus patch reef, eight distinct beds and five main facies are observed. Figure $2 a$ shows the beds and Fig. $2 b$ their interpretation. Most of the identified beds, with the exception of beds 5,6 and 7, can be laterally followed on either side of the coral-microbialite patch reef. Bed 7, very thin, is also present on both sides but is not continuous. Some of them (beds 1-4) display important lateral thickness changes. Bed 5 and 6 are only observed on the western side of the coral-microbialite patch reef.

The eight beds are characterised by facies variations (Fig. 2), whose macro- and microscopic analyses, facies textures and compositions are described in Online Resources 4 and 5. The facies are grouped into five main types: boundstone (Facies A and D), oolitic grainstone (Facies B, C, E, H and I), bioclastic grainstone (Facies F), oolitic and bioclastic packstone (Facies $\mathrm{C}$ and $\mathrm{E}$ ), and sandstone $(\mathrm{G})$. The oolitic grainstone is the dominant facies, and almost all the beds that were directly deposited around the reef totally or partly consist of that facies (Online resource $6 a, b$ ). The
The dashed lines correspond to the limit of possibly reef growth phases. They follow transversally surfaces correlating with the boundary of lateral beds

lateral beds 1-3 are mostly composed of grainstone and packstone generally rich in bioclasts and ooids (Facies B, C and E). Bed 4 is characterized by a bioclastic facies with grainstone textures (Facies F; Online resource 6c, d, e). Beds 5 and 7 are very thin, laterally discontinuous layers of sandstone rich in quartz (Facies G). Bed 6, lying between those two beds, is an oolitic grainstone (Facies $\mathrm{H}$ ) only observed on the western side of the coral-microbial patch reef. The outcrop ends with the thick bed 8 , made of ooids with a grainstone texture and high contents of quartz (Facies I). On the western side of the coral-microbialite patch reef, bed 8 shows horizontal to wavy layers and cross-lamination structures.

Important lateral facies variations, e.g., on the eastern side of the coral-microbialite patch reef, bed 2 is made either of a packstone/grainstone (Fig. 2: 2B) or of small oyster-microbialite bioconstructed patches (boundstone; Fig. 2: 2C; Online resource $6 f$, g). Contrastingly, on the western side, bed $2 \mathrm{~B}$ is characterised by a variety of 

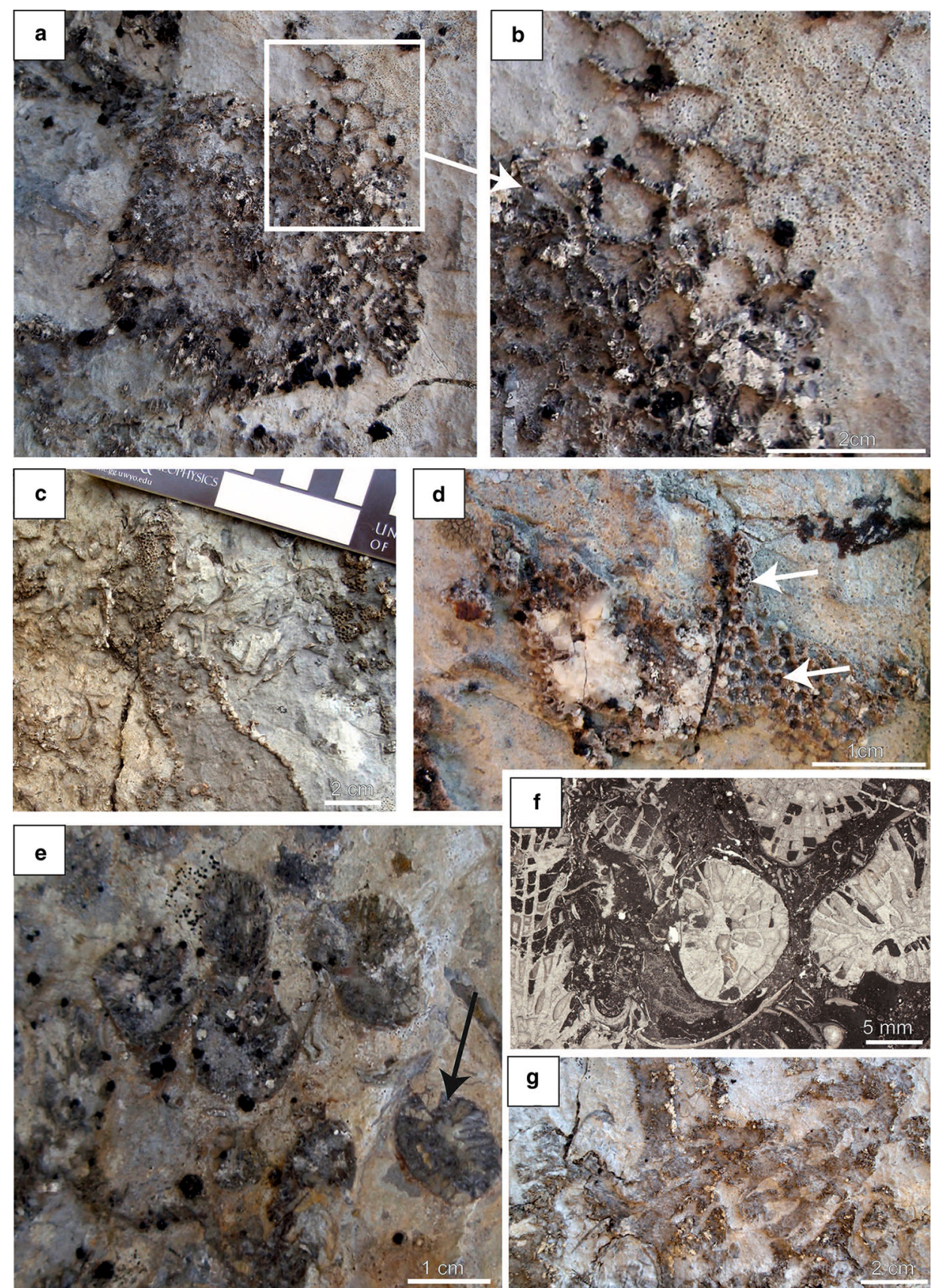

Fig. 3 Corals of the Le Perthus patch reef: a Lepidophyllia (Heterastraea) morencyana colony. b Detail of the colony (square in a) showing polygonal corallites. $\mathbf{c}$ Part of a branching Chondrocoenia clavellata colony. d Relatively well-preserved fragment of a Chondrocoenia colony. Small rounded corallites with prominent columella

packstone to grainstone facies without any bioconstructed structures inside. Bed 4 also shows some slight lateral facies variations, i.e., on the western part of the coral-microbialite patch reef, it contains few bioclasts, such as fragments of crinoids and dacycladacean algae but profuse ooids. are visible (arrows). e Transverse section of branches of the phaceloid Phacelostylophyllum ?suttonensis. Arrow indicates the best preserved corallite where septa are visible. $\mathbf{f}$ Thin section of the same colony shown in e. g Undetermined phaceloid colony (probably Phacelostylophyllum)

\section{Distribution and proportions of components in the Le Perthus patch reef}

Based on the described components, and to obtain more information on the structure of the Le Perthus patch reef, four horizontal transects were investigated (Fig. 4). The 
examination of the transects reveal that the reef volume is composed up to $70 \%$ of intercoral facies mainly secondary framebuilders (microbialites) and of a small proportion of trapped sediments (approximately 20-30\%) (Fig. 5). In the western part of the patch reef the proportion of primary framebuilders (corals) versus secondary framebuilders (e.g., microbialites, oysters, serpulids, and sponges) remains relatively stable vertically. Conversely, vertical variation is observed in its eastern part. Laterally, towards the east, the concentration of corals decreases. Indeed, the basal part of the section is formed by debris and microbialites (Online resource $7 \mathrm{f}$ ), whereas the upper part shows several coral colonies. From base to top, the concentration of coral slightly increases towards the top.

The proportions among coral genera are also relatively stable in the Le Perthus patch reef. The assemblage is homogeneously dominated by the genus Chondrocoenia. Conversely, Lepidophyllia, which is also well represented, becomes rarer towards the upper part and completely disappears laterally eastward. The phaceloid Phacelostylophyllum colonies are scarce and dispersed throughout the patch reef body; undetermined corals are abundant. However, the very irregular shapes of the latter suggest that they may be Chondrocoenia colonies implying that this genus is probably more abundant than estimated.

The percentage of bivalve shells becomes slightly higher in the upper part of the patch reef. With the exception of the oysters that are directly fixed on the corals, it seems that in the western part, the bivalves are mainly dislocated shell debris trapped in the reef framework. In the eastern part, the encrusting oysters and undetermined bivalves with thick walls are more abundant.

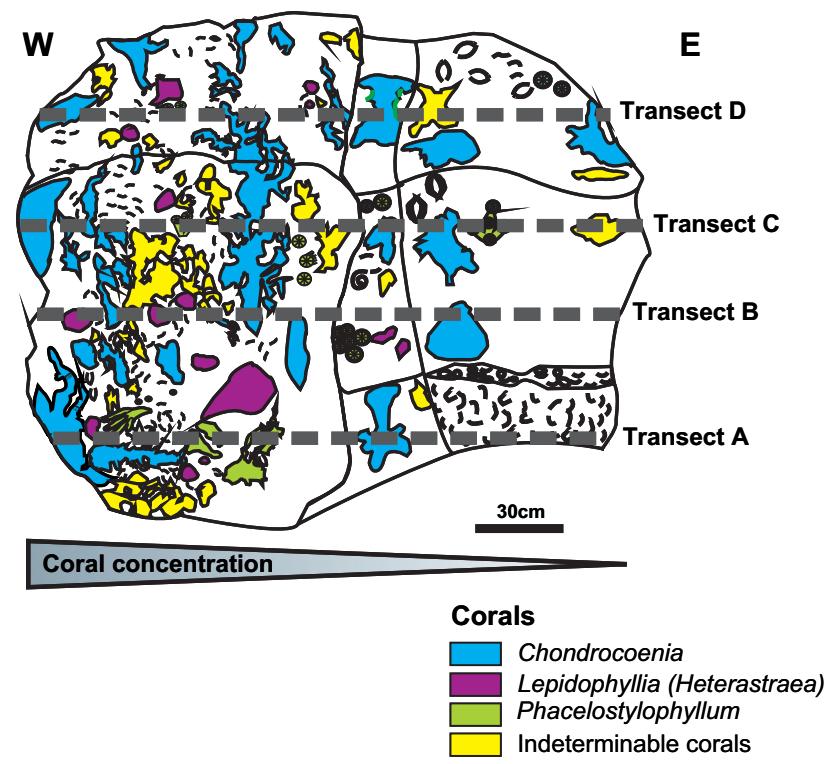

Fig. 4 Distribution of corals in the Le Perthus patch reef

\section{Discussion}

\subsection{Reef growth and depositional setting}

During the Late Jurassic coral-microbial reefs were widespread (e.g., Leinfelder et al. 1993, 2002; Schmid 1996; Leinfelder and Schmid 2000). Because they contribute fundamentally to the volumes and morphologies of some Jurassic reefs, microbialites can be considered to be part of the constructor guild (Leinfelder et al. 1996; Olivier et al. 2003). Hamon (2004) considered the intercoral facies of the Le Perthus patch reef to be composed exclusively by allochthonous mud that was trapped by corals. However, the detailed analysis of this bioconstruction does not support this interpretation. Microbialites are abundant in the Le Perthus patch reef, forming up to $50 \%$ of the bioconstruction. The Le Perthus patch reef is, therefore, a new example of an Early Jurassic coral-microbialite reef body. The presence of microbialites, and the associated micro-encrusters, provides significant evidence on the palaeoenvironmental conditions during patch reef development (Dupraz and Strasser 1999, 2002; Olivier et al. 2006, 2007).

The Le Perthus patch reef established in a shallow innerramp setting, characterized by a sand shoal made of ooidal grainstone (Hamon 2004; Hamon and Merzeraud 2007). The deposition of mud was rare, and the presence of ooids resulted from a high hydrodynamic energy. This hypothesis is corroborated by the observation of small oyster-microbialite bioconstructed patches, found in bed 2B (eastern side of the patch reef; Fig. 2), which were probably rolled, due to sporadic storms. The strong lateral thickness variations together with the structures of the beds, indicate that the reef evolved in a context of migrating oolitic mega ripples influenced by swell. Although no clear indications regarding a tidal influence were observed, the tidal sedimentary systems in the Sinemurian of the Lodève region was described by Hamon and Merzeraud (2007); Hamon et al. (2005). Reefs that grew under similar hydrodynamic conditions have been described by e.g., Bertling and Insalaco (1998) in the Paris Basin, and Reolid et al. (2007) in the French Jura. However, in high-energy settings, patch reefs could only grow and maintain their morphologies if strong microbial binding is present. Without microbial mediation, reefs quickly disintegrated and deposited as reef rubble.

The coral-microbialite nature of the Le Perthus patch reef may be an indicator of a moderate to low sedimentation rate. Indeed, microbialites are closely dependent on sedimentation rate, e.g., the more microbial crusts a reef contains, the lower the sedimentation rate should have been (Leinfelder et al. 1993). Reef establishment commonly corresponds to decreases in sedimentation rates, and if inputs stop for a while, microbial crusts will start growing on locally available secondary 

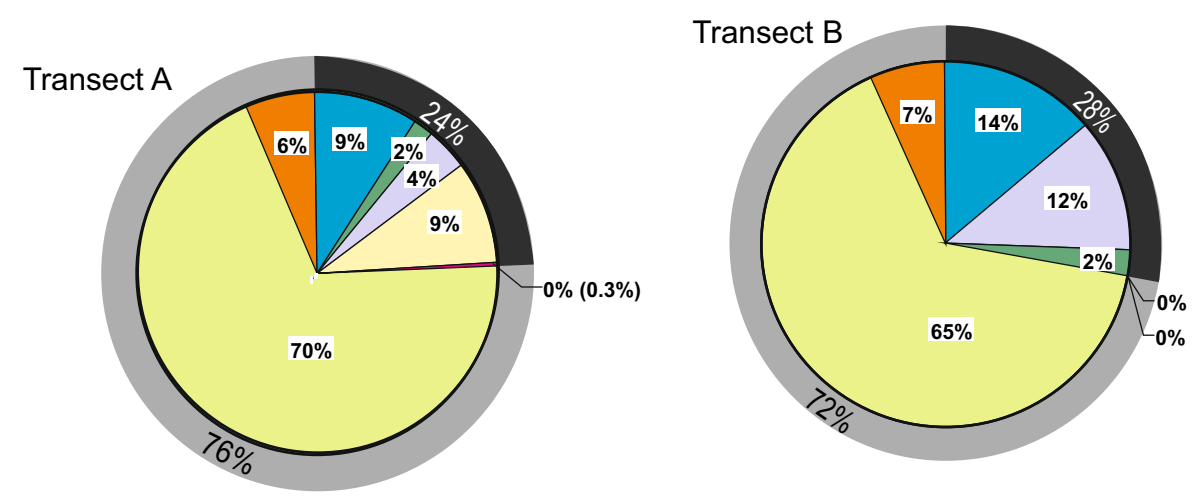

Proportions figured in the inner circle Genus Chondrocoenia?

$\square$ Genus Lepidophyllia

$\square$ Branched coral colonies

$\square$ Indeterminable corals

Neuropora

Intercoral facies

$\square$ Shelly Intercoral facies

Proportions figured in the outer circle

Binders (Intercoral fauna)

Constructors (corals + Neuropora)
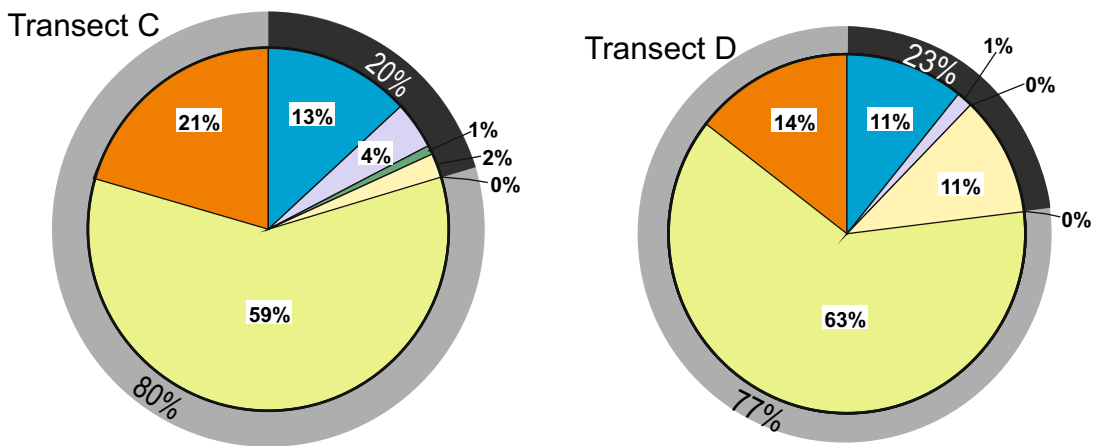

Fig. 5 Proportions of the different components of the Le Perthus patch reef

hardgrounds such as isolated bivalve shells (Leinfelder et al. 1993). The microbial crusts, which have the capability to rapidly blowout laterally, will then quickly provide a substrate on which other reefal organisms such as corals can settle (Leinfelder et al. 1993). That assumption is well proven and is observed in the eastern part of the Le Perthus patch reef. Here, it is clearly dominated by a microbialitic facies that definitely allowed the substrate to stabilise before the settlement of the corals. In its western part, laterally to the microbialites, corals of growth phase 1 were already developed (Fig. 2). Consecutive to the development of corals, during phases of low sedimentation rate a secondary framework constituted by microbialites and micro-encrusters established. Nevertheless, the environmental conditions were probably not optimal for reefal development as testified by the small size and of the Le Perthus patch reef. In this shallow setting, low accommodation space and migration of ooidal bars were possibly responsible for the short growth of the reef.

The initial settlement of the reef by microbialites occurred most likely during a short phase of non-deposition (Fig. 4). With the recovery of sedimentation, the corals developed preferentially on the western side, and the reef body acted as a shield, limiting sediment deposition on its eastern side. Accordingly, the debris trapped in the reefal structure are bigger and more concentrated on the western side, suggesting that the sediments were dominantly transported from west to east (Fig. 4). This configuration permitted the deposition of muddy facies (e.g., packstone of bed 2: Facies B, and of bed 3, Fig. 2) and the development of decimetre oyster-microbialite bioconstructions (bed 2: Facies C, Fig. 2) on the eastern side of the Le Perthus patch reef. The polarity of the geopetal structures reveals that these small bioconstructions were probably rolled. Hovewer, their decimetre size and the surrounding packstone facies suggest that they probably did not develop very far from the Le Perthus patch reef, which protected them in normal depositional conditions but e.g., not during storms.

The deposition of thick bed 4, having an erosive base, directly covers the top of the patch reef (Fig. 2). Its deposition possibly, but not necessarily, represents the cause of the demise of the Le Perthus patch reef. Thereafter, the shallowing-up evolution of the depositional sequence (Hamon 2004; Hamon et al. 2005; Hamon and Merzeraud 2007) and decrease in accommodation did not permit further reef growth. Hence, the death of the reef organisms was probably induced by modifications to the environmental conditions (i.e., shallowing-up) rather than a change in trophic level. The stenohaline fauna (corals, echinoderms, and sponges) indicates that normal marine conditions prevailed. The amounts of siliciclastic inputs are commonly correlated with nutrient rates (Dupraz 1999; Mutti and Hallock 2003). This study also shows that although the amount of quartz is not 
very high, the patch reef established in a setting where siliciclastic sediments were deposited.

Nutrient availability may be regarded as a factor that influences bioerosion. Indeed, bioeroding organisms are heterotrophic filter-feeders, and their abundance rise with increasing nutrient and food resources (Hallock 1988). In the Le Perthus patch reef, bioerosion is relatively diffuse; it is also commonly observed in the lateral oyster-microbialite bioconstructions.

Microbialites are, moreover, good indicators of nutrient availability. Indeed, high nutrient levels favour blooms of benthic microbial communities (e.g., Hallock and Schlager 1986; Camoin et al. 1999; McCook 2001; McCook et al. 2001; Sprachta et al. 2001). Olivier et al. (2006) concluded that periods of high nutrient concentrations (probably linked to terrigenous inputs) could have been responsible for the Bajocian coral-microbialite reefs growth. In the Upper Jurassic reefs, the micro-encrusters associations, dominated by serpulids and cyclostomate bryozoans, are considered opportunistic filter-feeding organisms that are not dependent on light (Dupraz 1999; Dupraz and Strasser 1999, 2002). In the Le Perthus patch reef, organisms associated with the corals are also dominantly filter-feeding (e.g., oysters and sponges). All these elements indicate that the patch reef most likely evolved in a global mesotrophic dominated system. Conversely, the trophic level could have varied while the reef was growing due to the shallowing-up of the setting (increase in siliciclastic inputs and consequent increase of nutrient supply). No clear evidence indicates the synchronicity between corals (primary framebuilders) and microbialites (secondary framebuilders). However, based on field observations, we suggest that corals developed in more oligotrophic settings than those of the secondary frame builders, dominated by microbialites.

\subsection{Are the corals of the Le Perthus patch reef Zooxanthellate?}

All the observations clearly indicate that the Le Perthus patch reef grew in a shallow setting under well-illuminated conditions. Nevertheless, being situated in the photic zone does not infer automatically that the corals were zooxanthellate. In Mesozoic corals, it is impossible to identify the presence of zooxanthellae because photosymbionts do not fossilize. In addition, the strong recrystallisation that often affects limestones prevent the use of geochemical proxies commonly used to detect zooxanthellate corals (e.g., Stanley and Swart 1995 with limitations given in Gill et al. 2004 and Cuif et al. 1999; Muscatine et al. 2005; Gautret et al. 1997; Tornabene et al. 2017). Indeed, they require very good preservation of the primary aragonite. However, analyses of the carbon and oxygen isotopes from both well preserved oyster shells and bulk-carbonates were performed in order to evaluate if the average temperature was compatible or not with the presence of zooxanthellae in the coral species of the Le Perthus patch reef (Online resources 9 to 11). The method based on growth bands to distinguish between symbiotic and non-symbiotic corals (Fagerstrom 1987; Stanley and Helmle 2010; Frankowiak et al. 2016) cannot be used either.

Only indirect observations, including the overall shape of the colonies, are here used as indicators of symbionts (Coates and Oliver 1973; Coates and Jackson 1987; Rosen and Turnšek 1989; Lathuilière 2000). Following Lathuilière (2000), the adoption by the same species of dome-shaped, three-dimensional colonies and plate-like, bi-dimensional growth forms, together with intermediate forms occurring between those two morphologies, and differential growth are made possible only by symbiosis. In the Le Perthus patch reef, Chondrocoenia clavellata displays high morphological plasticity with lamellar and branched colonies. The studied colonies of $C$. clavellata clearly exhibit a tendency to be branching. Dome-shaped and branching morphologies dominate the very shallow settings where light is abundant (Insalaco 1996a, b; Geister and Lathuilière 1991; Helm and Schülke 1998). Jaubert (1977) demonstrated similar relationships in shallow-water settings where, for instance, foliaceous morphotypes of Synaraea convexa in low-illuminated settings, grade into branching morphotypes in well-illuminated settings. Multiserial colonies exhibiting corallites smaller than $5 \mathrm{~mm}$ in diameter and displaying a high integration level may have hosted zooxanthellae (Coates and Jackson 1987). Summarising, colonies of $C$. clavellata have morpho-structural characteristics that may be considered as favourable indicators for the presence of symbionts: (i) branching forms, (ii) corallites with diameters less than $5 \mathrm{~mm}$, (iii) multiserial nature, and (iv) relatively high level of integration with their cerioid to plocoid arrangement.

This is not the case for the other genera from Le Perthus patch reef. Phacelostylophyllum has corallites with diameters exceeding $5 \mathrm{~mm}$ and has phaceloid morphology. It is not multiserial and has low integration level. Lepidophyllia colonies are intermediate: they have multiserial morphology, but their corallites are higher than $5 \mathrm{~mm}$. With cerioid arrangement, and imperforate connecting walls, they may be considered weakly integrated species. The diagnostic of the photosymbiosis is not straightforward for both genera. In conclusion, the coral assemblages of the Le Perthus patch reef were dominated by possibly zoxanthellate coral (C. clavellata) with subordinate associated species with uncertain photosymbiosis.

\subsection{Coral evolution and the T-J boundary crisis}

After the $\mathrm{T}-\mathrm{J}$ boundary mass extinction crisis, coral recovery started earlier in the Tethys and neighbouring epicontinental seas (West Europe, southern Europe, Carpathians, and North Africa) (Kiessling et al. 2009; Melnikova and Roniewicz 
2012). The magnitude of coral extinction rate during the $T-\mathbf{J}$ boundary is difficult to evaluate because of discrepancies in Triassic and Jurassic taxonomies (Kiessling et al. 2009; Lathuilière and Marchal 2009; Gretz et al. 2013). Lathuilière and Marchal (2009) reported that the extinction rate at the T-J boundary ranged between 50 and $60 \%$ at genus level. Kiessling et al. (2009) obtained an extinction rate of 51-53\% at genus level, excluding singletons.

Reef diversity and development truly recovered only during the Middle Jurassic (Lathuilière and Marchal 2009). Two genera at Le Perthus, Chondrocoenia and Phacelostylophyllum, can be certainly be considered as survivors of the T-J crisis in contrast to Lepidophyllia, wich is not known from the Triassic. The latter evolved from the Triassic family of stylophyllids and possibly was an evolutionary by-product of this crisis.

\subsection{The coral-microbialite reefs of the Early- Jurassic}

The $\mathrm{T}-\mathrm{J}$ boundary was characterised by a major biocalcification and coral reef crisis. Therefore, during the Lower Jurassic reefs were rare (e.g., Leinfelder et al. 2002; Melnikova and Roniewicz 2012). Corals and bivalves dominated the reef biotas of the post-Triassic, whereas sponges and microbialites were subordinate and mostly regional (Leinfelder et al. 2002). During the Triassic, corals formed well-developed biocostructions, whereas in the Early Jurassic corals occurred often as sparse colonies on marl, mud, and sand substrata (Melnikova and Roniewicz 2012). In Europe and in the Pamir Mountains, Hettangian?-Sinemurian coral colonies settled on unstable bottom sediments. Branching colonies usually formed meadow-like thickets, without real upward-growing bioconstructions (Melnikova and Roniewicz 2012). Even if their influence on sedimentation was restricted, Early Jurassic corals can be attributed more to the baffling- than to the constructorguilds (Leinfelder et al. 2002). The scarcity of constructor corals mirrors the paucity of reefal frameworks during the Hettangian and Sinemurian (Leinfelder et al. 2002). Following Kiessling et al. (2009), microbialites should not be taken as evidence of stress to explain the abundance of microbialites after mass extinctions. Indeed, microbial crusts were common components of reefs in the latest Triassic (e.g., Stanton and Flügel 1989; Flügel 2002) and Middle-Late Jurassic (e.g., Leinfelder et al. 2002; Olivier et al. 2006). The oldest known coral-microbialite reef is the Hettangian Elmi's reef (Ardèche, France) and it represents a unique example of this type of reef (Elmi 1990; Kiessling et al. 2009). Kiessling et al. (2009) suggested that the late Sinemurian Telkwa reef in British Columbia, described in several works (Poulton 1989; Stanley and McRoberts 1993; Stanley and Beauvais 1994), might be as prolific in microbialites as the Hettangian Elmi's reef. In the Hettangian?-Sinemurian coral facies of the southeastern Pamir Mountains, corals are commonly associated with structures of cyanobacterial origin (Melnikova and Roniewicz 2012).

In conclusion, as documented by the Le Perthus patch reef, the amount of microbialites in the Early Jurassic bioconstructions may have been higher than supposed and played an important role in the growth of Early Jurassic reefs. Abundant microbialites are not evidence of a major crisis as at T-J boundary (Kiessling et al. 2009) but were common components also in the latest Triassic (e.g., Stanton and Flügel 1989; Flügel 2002) and Middle-Late Jurassic (e.g., Leinfelder et al. 2002; Olivier et al. 2006).

\section{Conclusions}

The Le Perthus patch reef is a unique Sinemurian bioconstruction. Bio- and litho- facies suggest that it developed in a shallow mixed carbonate-siliciclastic setting. The reef was surrounded by a physical environment where ooids could form. The initial reef settlement occurred during a short phase of non-deposition. When the sedimentation became more important, the reef body acted as a shield, limiting sediment deposition on its eastern side. The reduced settling allowed the development of microbialites in the reef body, together with the formation of small bioconstructions mainly composed of oysters and microbialites on its eastern side. The growth of the Le Perthus patch reef was asymmetric, with initiation in the west and maximum development towards the east. The intercoral facies is mainly (up 70\%) composed of microbialites. Therefore, the reef can be defined as a coralmicrobialite reef, where microbialites played a major role in stabilising the reef body. Three coral genera are present: Chondrocoenia, Lepidophyllia and Phacelostylophyllum. Based on indirect observations, including the overall shape of the colonies, at least Chondrocoenia had zooxanthellae. The average temperatures $\left(20.83-25.83{ }^{\circ} \mathrm{C}\right)$, obtained from analyses of carbon and oxygen isotopes from both oyster shells and bulk-carbonates, are consistent with this assumption. Other biota in the bioconstruction are oysters, calcareous- and demo-sponges, and ostracods. Neuroporid sponges, rare in the main reef are more abundant at the sides. Micro-encrusters are diffuse but have low diversity, being composed of mainly serpulids. Foraminifers are almost absent and/or not biostratigraphically significant. The siliciclastic setting, rate of bioerosion and faunal assemblage indicate that the patch reef possibly evolved in a mesotrophic dominated system. Coral assemblages of the Le Perthus patch reef are formed by two Triassic genera: Chondrocoenia and Phacelostylophyllum that can be considered as survivors of the T-J crisis. In contrast, Lepidophyllia evolved from Triassic Stylophyllidae and 
should be considered an evolutionary by-product of the T-J boundary crisis.

Acknowledgements This contribution is part of an international collaboration aimed at evaluating palaeontological renewal through time and space as well as the palaeoecologic and palaeogeographic evolution of coral/reefal communities spanning the latest Triassic to Early Jurassic (Swiss NSF projects 200021_130238 and 200020_156422 to R.M.).

\section{References}

Alabouvette, B., Arrondeau, J.-P., Aubague, M., Bodeur, Y., Dubois, P., Mattei, J., et al. (1988). Notice explicative de la feuille le Caylar au 1/50 000 (p. 63). France: Éditions du BRGM.

Arrondeau, J.-P. (1982). Etude sédimentologique du Lias inférieur carbonaté du Seuil Caussenard et de ses abords (Languedoc). $\mathrm{PhD}$ dissertation. Université de Nantes, France, p. 281.

Bartolini, A., Guex, J., Spangenberg, J. E., Schoene, B., Taylor, D. G., Schaltegger, U., et al. (2012). Disentangling the Hettangian carbon isotope record: Implications for the aftermath of the endTriassic mass extinction. Geochemistry, Geophysics, Geosystems, 13(1), 1-11.

Baudrimont, A. F., \& Dubois, P. (1977). Un bassin mésogéen du domaine péri-alpin: le Sud-Est de la France. Bulletin du Centre de recherches Elf Exploration Production, Elf-Aquitaine, 1(1), 261-308.

Benton, M. J. (1995). Diversification and extinction in the history of life. Science, 268, 52-58.

Berner, R. A., \& Beerling, D. J. (2007). Volcanic degassing necessary to produce a $\mathrm{CaCO}_{3}$ undersaturated ocean at the TriassicJurassic boundary. Palaeogeography, Palaeoclimatology, Palaeoecology, 244(1-4), 368-373.

Bertling, M., \& Insalaco, E. (1998). Late Jurassic coral/microbial reefs from the northern Paris Basin-facies, palaeoecology and palaeobiogeography. Palaeogeography, Palaeoclimatology, Palaeoecology, 139, 139-175.

Camoin, G., Gautret, P., Montaggioni, L. F., \& Gabioch, G. (1999). Nature and environmental significance of microbialites in Quaternary reefs: The Tahiti paradox. Sedimentary Geology, 126, 271-304.

Clémence, M.-E., Bartolini, A., Gardin, S., Paris, G., Beaumont, V., \& Page, K. P. (2010a). Early Hettangian benthic-planktonic coupling at Doniford (SW England) Palaeoenvironmental implications for the aftermath of the end-Triassic crisis. Palaeogeography, Palaeoclimatology, Palaeoecology, 295, 102-115.

Clémence, M. E., Gardin, S., Bartolini, A., Paris, G., Beaumont, V., \& Guex, J. (2010b). Bentho-planktonic evidence from the Austrian Alps for a decline in sea-surface carbonate production at the end of the Triassic. Swiss Journal of Geosciences, 103, 293-315.

Coates, A. G., \& Jackson, B. C. (1987). Clonal growth, algal symbiosis, and reef formation by corals. Paleobiology, 13, 363-378.

Coates, A. G., \& Oliver, W. A. J. (1973). Coloniality in Zoantharian Corals. In R. S. Boardman, A. A. Cheetham, \& W. A. J. Oliver (Eds.), Animal colonies development and function through time (pp. 3-27). Dowden: Hutchinson \& Ross Inc.

Cuif, J. P., Dauphin, Y., Freiwald, A., Gautret, P., \& Zibrowius, H. (1999). Biochemical markers of zooxanthellae symbiosis in soluble matrices of skeleton of 24 Scleractinia species. Comparative Biochemistry Physiology A Molecular Integrative Physiology, 123(3), 269-278.
Debrand-Passard, S., Courbouleix, S., \& Lienhardt, M.-J. (1984). Synthèse géologique du Sud-Est de la France. Stratigraphie et paléogéographie BRGM., Orléans, p. 615.

Dupraz, C. (1999). Paléontologie, paléoécologie et évolution des faciès récifaux de l'Oxfordien moyen-supérieur (Jura suisse et français). PhD dissertation, Université de Fribourg, Switzerland, p. 200

Dupraz, C., \& Strasser, A. (1999). Microbialites and Micro-encrusters in shallow coral bioherms (Middle to Late Oxfordian, swiss Jura Mountains). Facies, 40, 101-130.

Dupraz, C., \& Strasser, A. (2002). Nutritional modes in coralmicrobialites reefs (Jurassic, Oxfordian, Switzerland): evolution of trophic structure as a response to environmental change. Palaios, 17, 449-471.

Elmi, S. (1990). Stages in the evolution of late Triassic and Jurassic carbonate platforms: the western margin of the Subalpine Basin (Ardèche, France). In M. E. Tucker, J. L. Wilson, P. D. Crevello, J. R. Sarg \& J. F. Read (Eds.), Carbonate Platforms: Facies, Sequences and Evolution (pp. 109-144). Special Publication international Association of Sedimentologists and Blackwell Scientific Publications, Oxford, London, Edinburgh, Boston, Melbourne.

Fagerstrom, J. A. (1987). The evolution of reef communities (p. 600). New York: Wiley.

Flügel, E. (2002). Triassic reef patterns. In W. Kiessling, E. Flügel, \& J. Golonka (Eds.), Phanerozoic reef patterns (pp. 391-463). SEPM Special Publication, 72. Tulsa, Oklahoma.

Flügel, E., \& Kiessling, W. (2002). Patterns of Phanerozoic reef crises. In W. Kiessling, E. Flügel, \& J. Golonka (Eds.), Phanerozoic Reef Patterns (pp. 691-733). SEPM Special Publication, 72. Tulsa, Oklahoma.

Frankowiak, K., Kret, S., Mazur, M., Meibom, A., Kitahara, M. V., \& Stolarski, J. (2016). Fine-scale skeletal banding can distinguish symbiotic from asymbiotic species among modern and fossil Scleractinian corals. PLoS One, 11(1), e0147066.

Gautret, P., Cuif, J. P., \& Freiwald, A. (1997). Composition of soluble mineralizing matrices in zooxanthellate and non-zooxanthellate scleractinian corals: Biochemical assessment of photosynthetic metabolism through the study of a skeletal feature. Facies, 36, 189-194.

Geister, J., \& Lathuilière, B. (1991). Jurassic Coral Reefs of the Northeastern Paris Basin (Luxembourg and Lorraine). In Excursions-guidebook, VII (pp. 112). Münster: Int. A. Symp. of. Fossil. Cnidaria and Porifera.

Gill, G. A., Santantonio, M., \& Lathuilière, B. (2004). The depth of pelagic deposits in the Tethyan Jurassic and the use of corals: An example from the Apennines. Sedimentary Geology, 166, 311-334.

Gretz, M., Lathuilière, B., \& Martini, R. (2015). A new coral with simplified morphology from the oldest known Hettangian (Early Jurassic) reef in southern France. Acta Paleontologica Polonica, 60(2), 277-286.

Gretz, M., Lathuilière, B., Martini, R., \& Bartolini, A. (2013). The Hettangian corals of the Isle of Skye (Scotland): An opportunity to better understand the palaeoenvironmental conditions during the aftermath of the Triassic-Jurassic boundary crisis. Palaeogeography, Palaeoclimatology, Palaeoecology, 376, 132-148.

Guex, J., Bartolini, A., Atudorei, V., \& Taylor, D. (2004). High resolution ammonite and carbon-isotope stratigraphy across the Triassic-Jurassic Boundary at New York Canyon (Nevada). Earth Planetary Science Letter, 225, 29-41.

Guex, J., Pilet, S., Müntener, O., Bartolini, A., Spangenberg, J., Schoene, B., et al. (2016). Thermal erosion of cratonic lithosphere as a potential trigger for mass-extinction. Nature Communication, Scientific Reports, 6, 23168. 
Guex, J., Schoene, B., Bartolini, A., Spangenberg, J. E., Schaltegger, U., O’Dogherty, L., et al. (2012). Geochronological constraints on post-extinction recovery of the ammonoids and carbon cycle perturbations during the Early Jurassic. Palaeogeography, Palaeoclimatology, Palaeoecology, 346, 1-11.

Hallock, P. (1988). The role of nutrient availibility in bioerosion: Consequences to carbonate buildups. Palaeogeography, Palaeoclimatology, Palaeoecology, 63, 275-291.

Hallock, P., \& Schlager, W. (1986). Nutrient excess and the demise of coral reefs and carbonate plateforms. Palaios, 1, 389-398.

Hamon, Y. (2004). Morphologie, évolution latérale et signification géodynamique des discontinuités sédimentaires Exemple du Lias de la marge Ouest du Bassin du Sud-Est (France). PhD dissertation, Université de Montpellier, France, 294 pp.

Hamon, Y., \& Merzeraud, G. (2007). C and O isotope stratigraphy in shallow-marine carbonate: A tool for sequence stratigraphy (example from the Lodève region, peritethian domain). Swiss Journal of Geosciences, 100(1), 71-84.

Hamon, Y., Merzeraud, G., \& Combes, P.-J. (2005). Des cycles hautes fréquences de variations du niveau marin relatif enregistrés dans les discontinuités sédimentaires: Un exemple dans le Lias inférieur de Lodève (Sud-Est de la France). Bulletin de la Société géologique de France, 176(1), 57-68.

Hautmann, M. (2004). Effect of end-Triassic $\mathrm{CO}_{2}$ maximum on carbonate sedimentation and marine mass extinction. Facies, 50(2), 257-261.

Hautmann, M. (2006). Shell mineralogical trends in epifaunal Mesozoic bivalves and their relationship to seawater chemistry and atmospheric carbon dioxide concentration. Facies, 52, 417-433.

Helm, C., \& Schülke, I. (1998). A coral-microbialite Patch Reef from the Late Jurassic (florigemma-Bank, Oxfordian) of NW Germany (Süntel Mountains). Facies, 39, 75-104.

Hesselbo, S. P., Robinson, S. A., Surlyk, F., \& Piasecki, S. (2002). Terrestrial and marine extinction at the Triassic-Jurassic boundary synchronized with major carbon-cycle perturbation: A link to initiation of massive volcanism? Geology, 30, 251-254.

Hönish, B., Ridgwell, A., Schmidt, D. N., Thomas, E., Gibbs, S. J., Sluijs, A., et al. (2012). The geological record of ocean acidification. Science, 335, 1058-1063.

Insalaco, E. (1996a). The use of Late Jurassic coral growth bands as palaeoenvironmental indicators. Palaeontology, 39, 413-431.

Insalaco, E. (1996b). Upper Jurassic microsolenid biostromes of northern and central Europe: Facies and depositionnal environment. Palaeogeography, Palaeoclimatology, Palaeoecology, 121, 169-194.

Jaubert, J. (1977). Light, metabolism and growth forms of the hermatypic scleractinian coral Synarea convexa Verrill in the lagoon of Moorea (French Polynesia). Proceedings 3rd International Coral Reef Symposium Miami, 1, 483-488.

Kasprak, A. H., Sepúlveda, J., Price-Waldman, R., Williford, K. H., Schoepfer, S. D., Haggart, J. W., et al. (2015). Episodic photic zone euxinia in the northeastern Panthalassic Ocean during the end-Triassic extinction. Geology, 43(4), 307-310.

Kiessling, W. (2011). Patterns and process of ancient reef crises. Paleontological Society Papers, 17, 1-14.

Kiessling, W., Aberhan, M., Brenneis, B., \& Wagner, P. J. (2007). Extinction trajectories of benthic organisms across the TriassicJurassic boundary. Palaeogeography, Palaeoclimatology, Palaeoecology, 244(1-4), 201-222.

Kiessling, W., Flügel, E., \& Golonka, J. (1999). Paleoreef maps: Evaluation of a comprehensive database on phanerozoic reefs. American Association of Petroleum Geologists Bulletin, 83(10), $1552-1587$.

Kiessling, W., Roniewicz, E., Villier, L., Léonide, P., \& Struck, U. (2009). An Early Hettangian coral reef in southern France:
Implications for the end-Triassic reef crisis. Palaios, 24, 657-671.

Lathuilière, B. (2000). Coraux constructeurs du Bajocien inférieur de France. 2ème partie. Geobios, 33, 153-181.

Lathuilière, B., \& Marchal, D. (2009). Extinction, survival and recovery of corals from the Triassic to Middle Jurassic time. Terra Nova, 21(1), 57-66.

Leinfelder, R. R., Nose, M., Schmid, D. U., \& Werner, W. (1993). Microbial crusts of the Late Jurassic: Composition, palaeoecological significance and importance in reef construction. Facies, 29, 195-230.

Leinfelder, R. R., \& Schmid, D. U. (2000). Mesozoic reefal thrombolites and other Microbolites. In R. E. Riding \& S. M. Awramik (Eds.), Microbial sediments (pp. 289-294). Berlin: Springer.

Leinfelder, R. R., Schmid, D. U., Nose, M. \& Werner, W. (2002). Jurassic reef patterns-The expression of a changing globe. Patterns of Phanerozoic reef crises. In W. Kiessling, E. Flügel, \& J. Golonka (Eds.), Phanerozoic Reef Patterns (pp. 465-520). SEPM Special Publication, 72. Tulsa, Oklahoma.

Leinfelder, R. R., Werner, W., \& Nose, M. (1996). Paleoecology, growth parameters and dynamics of coral, sponge and microbolite reefs from the late jurassic. In J. Reitner, F. Neuweiler, \& F. Gunkel, F. (Eds.), Global and regional controls on biogenic sedimentation. I. Reef evolution. Sb2 (pp. 227-248). Research Reports, Göttinger Arbeiten zur Geologie und Paläontologie.

Martindale, R. C., Berelson, W. M., Corsetti, F. A., Bottjer, D. J., \& West, A. J. (2012). Constraining carbonate chemistry at a potential ocean acidification event (the Triassic-Jurassic boundary) using the presence of corals and coral reefs in the fossil record. Palaeogeography, Palaeoclimatology, Palaeoecology, 350-352, 114-123.

Marzoli, A., Renne, P. R., Piccirillo, E. M., Ernesto, M., Bellieni, G., \& DeMin, A. (1999). Extensive 200-million-year-old continental flood basalts of the Central Atlantic Magmatic Province. Science, 284, 616-618.

McCook, L. J. (2001). Competition between corals and algal turfs along a gradient of terrestrial influence in the nearshore central Great Barrier Reef. Coral Reefs, 19, 419-425.

McCook, L. J., Jompa, J., \& Diaz-Pulido, G. (2001). Competition between corals and algae on coral reefs. Coral Reefs, 19, 400-417.

McElwain, J. C., Beerling, D. J., \& Woodward, F. I. (1999). Fossil plants and global warming at the Triassic-Jurassic boundary. Science, 285, 1386-1390.

McElwain, J. C., Wagner, P. J., \& Hesselbo, S. P. (2009). Fossil plant relative abundances indicate sudden loss of Late Triassic biodiversity in East Greenland. Science, 324, 1554-1556.

McRoberts, C. A., Krystyn, L., \& Hautmann, M. (2012). Macrofaunal response to the end-Triassic mass extinction in the West-Tethyan Kössen Basin, Austria. Palaios, 27(9), 607-616.

Melas, P. (1982). Etude sédimentologique. paléogéographique et géochimique du Lias carbonaté du Nord-Lodèvois. Application à la reconnaissance et à l'interprétation d'amas metallifères Mémoire du Centre d'Etudes et de Recherches Géologiques et Hydrogéologiques. Université des Sciences et Techniques du Languedoc. Montpellier II, p. 419.

Melnikova, G. K., \& Roniewicz, E. (2012). Early Jurassic corals of the Pamir Mountains- a new Triassic-Jurassic transitional fauna. Geologica Belgica, 15(4), 376-381.

Merzeraud, G., \& Colombié, C. (1999). Evolution morphologique des profils de dépôts dans le Sinémurien de la marge cévenole (région de Lodève). Comptes Rendus de l'Académie des Sciences-Series IIA-Earth and Planetary Science, 329(11), 779-786.

Michard, A., Aubague, M., Lefavrais-Raymond, A., \& L'Homer, A. (1979). Le Lotharingien supérieur dans le bassin des Causses: 
stratigraphie et évolution du bassin. Bulletin de la Société géologique de France, 7(t. XXI, n $\left.{ }^{\circ}\right), 3-10$.

Muscatine, L., Goiran, C., Land, L., Jaubert, J., Cuif, J. P., \& Allemand, D. (2005). Stable isotopes (d13C and d15 N) of organic matrix from coral skeleton. Proceedings of the National Academy of Sciences, 102, 1525-1530.

Mutti, M., \& Hallock, P. (2003). Carbonate systems along nutrient and temperature gradients: Some sedimentological and geochemical constraints. International Journal of Earth Sciences, 92(4), 465-475.

Newell, N. D. (1963). Crises in the history of life. Scientific American, 208(2), 76-95.

Olivier, N., Hantzpergue, P., Gaillard, C., Pittet, B., Leinfelder, R. R., Schmid, D. U., et al. (2003). Microbialite morphology, structure and growth: A model of the Upper Jurassic reefs of the Chay Peninsula (western France). Palaeogeography, Palaeoclimatology, Palaeoecology, 193, 383-404.

Olivier, N., Lathuilière, B., \& Thiry-Bastien, P. (2006). Growth models of Bajocian coral-microbialite reefs of Chargey-lès-Port (eastern France): Palaeoenvironmental interpretations. Facies, 52, 113-127.

Olivier, N., Pittet, B., Gaillard, C., \& Hantzpergue, P. (2007). Highfrequency palaeoenvironmental fluctuations recorded in Jurassic coral-and sponge-microbialite bioconstructions. Comptes Rendus Palevol, 6, 21-36.

Olsen, P. E., Kent, D. V., Sues, H.-D., Koeberl, C., Huber, H., Montanari, A., et al. (2002). Ascent of dinosaurs linked to Ir anomaly at Triassic-Jurassic boundary. Science, 296, 1305-1307.

Pálfy, J., Demeny, A., Haas, J., Htenyi, M., Orchard, M. J., \& Veto, I. (2001). Carbon isotope anomaly at the Triassic-Jurassic boundary from a marine section in Hungary. Geology, 29, 1047-1050.

Poulton, T. P. (1989). A Lower Jurassic coral reef, Telkwa Range, British Columbia. Canadian Society of Petroleum Geologists Memoir, 13, 754-757.

Raup, D. M., \& Sepkoski, J. J. (1982). Mass extinctions in the marine fossil record. Science, 215(4539), 1501-1503.

Reolid, M., Gaillard, C., \& Lathilière, B. (2007). Microfacies, microtaphonomic traits and foraminiferal assemblages from Upper Jurassic oolitic-coral limestones: Stratigraphic fluctuations in a shallowing-upward sequence (French Jura, Middle Oxfordian). Facies, 53, 553-574.

Richoz, S., van de Schootbrugge, B., Pross, J., Puttmann, W., Quan, T. M., Lindström, S., et al. (2012). Hydrogen sulphide poisoning of shallow seas following the end-Triassic extinction. Nature Geoscience, 5, 662-667.

Rosen, B. R., \& Turnšek, D. (1989). Extinction patterns and biogeography of scleractinian corals across the Cretaceous/ Tertiary boundary. Memoirs of the Association of Australasian Paeontologists, 8, 355-370.

Ruhl, M., Bonis, N. R., Reichart, G.-J., Sinninghe Damsté, J. S., \& Kurschner, W. M. (2011). Atmospheric carbon injection linked to end-triassic mass extinction. Science, 333, 430-434.

Schaltegger, U., Guex, J., Bartolini, A., Schoene, B., \& Ovtcharova, M. (2008). Precise U-Pb age constraints for end-Triassic mass extinction, its correlation to volcanism and Hettangian postextinction recovery. Earth and Planetary Science Letters, 267, 266-275.

Schmid, D. U. (1996). Marine Mikrobolithe und Mikroinkrustierer aus dem Oberjura. Profil, 9, 101-251.

Schmieder, M., Buchner, E., Schwarz, W. H., Trieloff, M., \& Lambert, P. (2010). A Rhaetian 40Ar/39Ar age for the
Rochechouart impact structure (France) and implications for the latest Triassic sedimentary record. Meteoritics \& Planetary Science, 45, 1225-1242.

Schoene, B., Guex, J., Bartolini, A., Schaltegger, U., \& Blackburn, T. J. (2010). Correlating the end-Triassic mass extinction and flood basalt volcanism at the $100 \mathrm{ka}$ level. Geology, 38, 387-390.

Sprachta, S., Camoin, G., Golubic, S., \& Le Campion, T. (2001). Microbialites in a modern lagoonal environment: Nature and distribution, Tikehau atoll (French Polynesia). Palaeogeography, Palaeoclimatology, Palaeoecology, 175, 103-124.

Stanley, G. D., Jr. (2001). Introduction to Reef Ecosystems and Their Evolution. In G. D. Jr Stanley (Ed.), The history and sedimentology of ancient reef systems (17th ed., pp. 1-39). New York: Kluwer academic/Plenum Publishers.

Stanley, G. D., Jr., \& Beauvais, L. (1994). Corals from an Early Jurassic coral reef in British Columbia: Refuge on an oceanic island reef. Lethaia, 27(1), 34-47.

Stanley, G. D., Jr., \& Helmle, K. P. (2010). Middle Triassic coral growth bands and their implication for photosymbiosis. Palaios, 25, 754-763.

Stanley, G. D., Jr., \& McRoberts, C. A. (1993). A coral reef in the Telkwa Range, British Columbia: The earliest Jurassic example. Canadian Journal of Earth Sciences, 30, 819-831.

Stanley, G. D., Jr., \& Swart, P. (1995). Evolution of the coralzooxanthellae symbiosis during the Triassic: A geochemical approach. Paleobiology, 21, 179-199.

Stanton, R. J., \& Flügel, E. (1989). Problems with reef models: The Late Triassic Steinplatte 'reef' (Northern Alps, Salzburg/Tyrol, Austria). Facies, 20, 1-138.

Tanner, L. H., Hubert, J. F., Coffey, B. P., \& McInerney, D. P. (2001). Stability of atmospheric $\mathrm{CO}_{2}$ level across the Triassic-Jurassic boundary. Nature, 411, 675-677.

Tanner, L. H., Lucas, S. G., \& Chapman, M. G. (2004). Assessing the record and causes of Late Triassic extinctions. Earth-Science Reviews, 65(1-2), 103-139.

Tornabene, C., Martindale, R. C., Wang, X. T., \& Schaller, M. F. (2017). Detecting photosymbiosis in fossil scleractinian corals. Scientific Reports, 7, Art. Numb. 9465.

Van de Schootbrugge, B., Payne, J. L., Tomasovych, A., Pross, J., Fiebig, J., Brenbrahim, M., et al. (2008). Carbon cycle perturbation and stabilization in the wake of the Triassic-Jurassic boundary mass-extinction event. Geochemistry, Geophysics, Geosystems, 9(4), Q04028.

Van de Schootbrugge, B., Quan, T. M., Lindström, S., Pütmann, W., Heunisch, C., Pross, J., et al. (2009). Floral changes across the Triassic/Jurassic boundary linked to flood basalt volcanism. Nature Geoscience, 2, 589-594.

Van de Schootbrugge, B., Tremolada, F., Rosenthal, Y., Bailey, T. R., Feist-Birkhardt, S., Brinkhuis, H., et al. (2007). End-Triassic calcification crisis and blooms of organic-walled 'disaster species'. Palaeogeography, Palaeoclimatology, Palaeoecology, 244, 12-141.

Van de Schootbrugge, B., \& Wignall, P. B. (2015). A tale of two extinctions: converging end-Permian and end-Triassic scenarios. Geological Magazine, 153(2), 332-354.

Ward, P. D., Haggart, J. W., Carter, E. S., Wilbur, D., Tipper, H. W., \& Evans, T. (2001). Sudden productivity collapse associated with the Triassic-Jurassic boundary mass extinction. Science, 292, 1148-1151. 